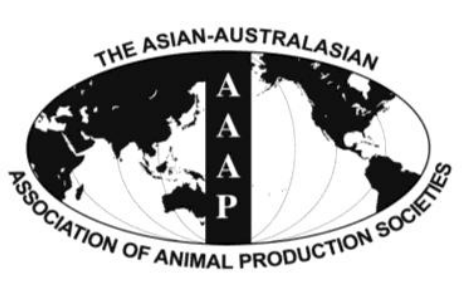

Open Access

Asian Australas. J. Anim. Sci.

Vol. 27, No. 9 : 1360-1367 September 2014

http://dx.doi.org/10.5713/ajas.2014.14110

www.ajas.info

pISSN 1011-2367 elSSN 1976-5517

\title{
Changes in Hematological, Biochemical and Non-specific Immune Parameters of Olive Flounder, Paralichthys olivaceus, Following Starvation
}

\author{
Jong-Hyun Kim*, Min Hwan Jeong, Je-Cheon Jun, and Tae-Ik Kim ${ }^{1}$ \\ Aquaculture Research Institute, National Fisheries Research and Development Institute, Busan 619-705, Korea
}

\begin{abstract}
Triplicate groups of fed and starved olive flounder, Paralichthys olivaceus (body weight: $119.8 \pm 17.46 \mathrm{~g}$ ), were examined over 42 days for physiological changes using hematological, biochemical, and non-specific immune parameters. No significant differences in concentrations of blood hemoglobin and hematocrit and plasma levels of total cholesterol, aspartate aminotransferase, alanine aminotransferase, glucose, and cortisol were detected between fed and starved groups at any sampling time throughout the experiment. In contrast, plasma total protein concentrations were significantly lower in starved fish than in fed fish from day 7 onwards. Moreover, plasma lysozyme concentrations were significantly higher in starved flounder from day 21 onwards. This result confirms that the response of olive flounder to short-term (less than about 1.5 months) starvation consists of a readjustment of metabolism rather than the activation of an alarm-stress response. The present results indicate that starvation does not significantly compromise the health status of fish despite food limitation. (Key Words: Olive Flounder, Paralichthys olivaceus, Growth, Hematological Response, Biochemical Response, Lysozyme Activity, Food Deprivation)
\end{abstract}

\section{INTRODUCTION}

The quality of farmed fish is becoming increasingly important within the aquaculture industry, and levels of feeding and starvation are crucial factors that determine product quality (Ogata et al., 2002; Park et al., 2006). In Korea, temporal starvation occurs at farms of olive flounder, Paralichthys olivaceus, in response to natural environmental fluctuations. For example, fish are commonly starved under feeding restricted regimes to minimize fish mortality during undesirable environmental conditions such as red tides or cold-water masses in the summer (Cho et al., 2006; Park et al., 2012). These starvation periods may produce hormonal and biochemical changes. Accordingly, a better understanding of the effects of starvation on fish physiology and of the nutrient requirements for optimal growth performance is crucial for

\footnotetext{
* Corresponding Author: Jong-Hyun Kim. Tel: +82-51-720-2820, Fax: +82-51-720-2828, E-mail: johnkim@korea.kr

${ }^{1}$ Southwest Sea Fisheries Research Institute, National Fisheries Research and Development Institute, Yeosu 556-823, Korea.

Submitted Feb. 13, 2014; Revised Apr. 12, 2014; Accepted Apr. 24, 2014
}

profitable fish farming (Chatzifotis et al., 2011).

Different fish species tolerate starvation periods using distinct strategies of activating adaptive biochemical and physiological mechanisms that enable them to cope with the adverse condition (Bandeen and Leatherland, 1997; Barcellos et al., 2010; Caruso et al., 2012). These tactics include endocrine changes such as modifications in plasma cortisol concentrations and metabolic changes such as varying the use of carbohydrates, lipids, and proteins from different body compartments in response to food deprivation. In many studies, cortisol concentrations were significantly higher in starved fish than in fed fish (Barcellos et al., 2010; Costas et al., 2011; Caruso et al., 2012). However, some reports have documented decreased cortisol concentrations in starved fish (Barton et al., 1988; Small, 2005), whereas others have found no consistent effects (Farbridge and Leatherland, 1992; Davis and Gaylord, 2011). In terms of metabolic changes, some fish such as northern pike, Esox lucius, and golden perch, Macquaria ambigua, use lipids as a primary and early source of energy during starvation (Ince and Thorpe, 1976; Collins and Anderson, 1995), whereas others such as red 
porgy, Pagrus pagrus, use muscle protein (Rueda et al., 1998). Alternatively, species such as cod, Gadus morhua, and coho salmon, Oncorhynchus kisutch, partially deplete stored carbohydrates in the form of glycogen in the liver (Hemre et al., 1993; Larsen et al., 2001).

In olive flounder, the effects of starvation on growth, phenotypic traits, blood chemistry, physicochemical characteristics of muscle, hepatocyte ultrastructure, the kidney melano-macrophage center, and respiratory exchange have been well studied (Hur et al., 2006a,b; Park et al., 2006,2007; Cho, 2009; Park et al., 2012; Shim et al., 2012). However, current knowledge of starvation effects, especially within the first 4 weeks of starvation, on some hormonal and immune responses such as changes in plasma cortisol and lysozymes is limited, thus hindering an integrated understanding of biochemical and immunological changes in olive flounder. We investigated the changes in the growth, hematological, biochemical, and non-specific immune parameters induced by starvation of olive flounder. In particular, blood hemoglobin and hematocrit and plasma levels of total protein, total cholesterol, aspartate aminotransferase (AST), alanine aminotransferase (ALT), glucose, cortisol, and lysozyme were measured and compared in starved and fed fish.

\section{MATERIALS AND METHODS}

Six-month-old olive flounder $(n=240$, mean total length: $22.5 \pm 1.13 \mathrm{~cm}$; mean body weight: $119.8 \pm 17.46 \mathrm{~g}$ ) obtained from a private fish farm were used for the experiment. Fish were reared in 1.8-ton circular fiberglass reinforced plastic tanks (150-cm diameter $\times 100-\mathrm{cm}$ depth) at the aquaculture experimental facility of the National Fisheries Research and Development Institute, Busan, Korea. The fish were randomly distributed into six tanks (three tanks for each of two experimental groups, fed and starved) with 40 fish in each tank. The tanks were supplied with seawater $(33.7 \pm 0.63 \mathrm{psu}$; filtered through sand, 0.5 to $1.0 \mathrm{~mm}$ in diameter) via a flow-through system. The water temperature was maintained at $19.9^{\circ} \mathrm{C}$ to $20.9^{\circ} \mathrm{C}$ $\left(20.4 \pm 0.21^{\circ} \mathrm{C}\right)$. A diurnal light:dark cycle was provided by natural conditions and supplemented by fluorescent light during the daytime. All fish were hand-fed a commercial fish diet containing $52.0 \%$ crude protein and $11.0 \%$ crude lipid (Suhyup Feed, Uiryeong, Gyeongnam, Korea) to visual satiety twice a day (09:00 and 17:00 h) for 2 weeks prior to the start of the experiment. Throughout the experiment, the fed group received the commercial diet ad libitum, whereas nothing was provided to the starved group. Data on water temperature, salinity, and mortality were recorded daily.

The experiment consisted of eight samplings performed
$0,4,7,14,21,28,35$, and 42 days after the onset of the experiment. The fed group was starved for $24 \mathrm{~h}$ before blood sampling. Blood samples were taken by means of a heparinized syringe from the caudal vein of five fish from each tank after being anesthetized with 2-phenoxy-ethanol (Sigma-Aldrich, St. Louis, MO, USA) at a concentration of $300 \mathrm{mg} / \mathrm{L}$. Small volumes of blood were used for the immediate determination of hematocrit and hemoglobin values. The remaining blood was centrifuged at 3,500 $\mathrm{g}$ for $5 \mathrm{~min}$, and the obtained plasma was stored at $-75^{\circ} \mathrm{C}$ as separate aliquots for subsequent biochemical and immunological analysis.

Hematocrit values (\% red blood cells) were determined in heparinized capillary tubes after centrifugation in a standard microhematocrit centrifuge at $12,000 \mathrm{~g}$ for $5 \mathrm{~min}$; the capillary tube was compared to a reference scale. The concentrations of blood hemoglobin and plasma levels of total protein, total cholesterol, AST, ALT, and glucose were analyzed using an automatic biochemistry analyzer (Fuji Dri-Chem 3500i; Fuji Photo Film, Tokyo, Japan). Plasma cortisol concentrations were measured using a chemiluminescence enzyme immunoassay with a commercial kit (Coat-A-Count; Siemens Medical Diagnostics, Los Angeles, CA, USA) and a Cobra II gamma counter (Hewlett Packard, Palo Alto, CA, USA). The intraand inter-assay variations in the precision coefficient ranges for cortisol were $3.0 \%$ to $5.1 \%$ and $4.0 \%$ to $6.4 \%$, respectively. Plasma lysozyme concentrations were determined via turbidimetry as described by Parry et al. (1965) using $0.2 \mathrm{mg} / \mathrm{mL}$ lyophilized Micrococcus lysodekticus (Sigma-Aldrich, St. Louis, MO, USA) as the substrate in $0.05 \mathrm{M}$ sodium phosphate buffer ( $\mathrm{pH}$ 6.2). Plasma (100 $\mu \mathrm{L})$ was added to $100 \mu \mathrm{L}$ bacterial suspension, and the mixture was incubated at $37^{\circ} \mathrm{C}$. Sample absorbance was measured at intervals of 0.5 and $4.5 \mathrm{~min}$ on a spectrophotometer at $550 \mathrm{~nm}$. A lysozyme activity unit was defined as the amount of enzyme producing a decrease in absorbance of $0.001 / \mathrm{min}$.

Data are shown as means \pm standard error of the triplicates in each experimental group. All data were compared using one-way analysis of variance, followed by Duncan's multiple range tests to determine significant differences between means. All statistical analyses were performed using SAS package version 9.13 (SAS Institute, Cary, NC, USA).

\section{RESULTS}

At the start of the experiment, the mean total length and body weight of the olive flounder were $22.5 \pm 1.13 \mathrm{~cm}$ and $119.8 \pm 17.46 \mathrm{~g}$, respectively, in both experimental groups. At the end of the experiment (42 days later), the total length 
and body weight of the fed group were $26.9 \pm 1.47 \mathrm{~cm}$ and $215.8 \pm 39.66 \mathrm{~g}$, respectively, while the values for the starved group were $22.8 \pm 1.24 \mathrm{~cm}$ and $105.6 \pm 15.85 \mathrm{~g}$, respectively. Mortality was low, as only three fish died throughout the experiment, and no difference in survival was found between groups (data not shown).

The effects of starvation on hematological parameters are shown in Table 1. Over the entire experiment, neither hematocrit nor hemoglobin significantly differed between the experimental groups at any sampling time $(p>0.05)$, although hematocrit had significantly decreased in the fed fish on day 14 (16.4\% of the initial value) and hemoglobin had significantly increased in the starved fish on days 7,21 , and $42(19.6 \%$ to $27.1 \%$ of the initial value, $\mathrm{p}<0.05)$.

The effects of starvation on biochemical parameters are presented in Table 2 to 4 . The concentrations of total protein after day 4 in the fed group (mean concentration of 4.49 $\mathrm{g} / \mathrm{dL})$ were statistically similar to the concentration (4.45 $\mathrm{g} / \mathrm{dL}$ ) observed on day 0 ( $\mathrm{p}>0.05)$, whereas the values in the starved group decreased significantly as starvation time increased; concentrations fell from $4.37 \pm 0.060 \mathrm{~g} / \mathrm{dL}$ on day 0 to $3.42 \pm 0.029 \mathrm{~g} / \mathrm{dL}$ on day 7 and to $2.74 \pm 0.062 \mathrm{~g} / \mathrm{dL}$ on day $42(\mathrm{p}<0.05$; Table 2$)$. As a result, total protein concentrations in the starved group were significantly lower than those in the fed group from day 7 onwards $(\mathrm{p}<0.01$ or

Table 1. Values of hematological parameters measured in starved and fed olive flounder, Paralichthys olivaceus, 0, 4, 7, 11, 14, 21, 28,35 , and 42 days after the start of the experiment

\begin{tabular}{cccc}
$\begin{array}{c}\text { Time } \\
\text { (days) }\end{array}$ & Fed & Starved & $\begin{array}{c}\text { Fed vs } \\
\text { starved }\end{array}$ \\
\hline $\begin{array}{c}\text { Hematocrit (\% red blood cell) } \\
0\end{array}$ & $26.8 \pm 1.01^{\mathrm{a}}$ & $25.3 \pm 0.60^{\mathrm{ab}}$ & $\mathrm{NS}$ \\
4 & $25.7 \pm 1.00^{\mathrm{ab}}$ & $24.9 \pm 1.06^{\mathrm{ab}}$ & $\mathrm{NS}$ \\
7 & $25.2 \pm 1.37^{\mathrm{ab}}$ & $24.7 \pm 0.51^{\mathrm{b}}$ & $\mathrm{NS}$ \\
14 & $22.4 \pm 1.25^{\mathrm{b}}$ & $23.0 \pm 1.58^{\mathrm{b}}$ & $\mathrm{NS}$ \\
21 & $25.7 \pm 0.69^{\mathrm{ab}}$ & $26.6 \pm 1.42^{\mathrm{ab}}$ & $\mathrm{NS}$ \\
28 & $24.3 \pm 0.88^{\mathrm{ab}}$ & $23.9 \pm 1.79^{\mathrm{b}}$ & $\mathrm{NS}$ \\
35 & $27.1 \pm 0.29^{\mathrm{a}}$ & $29.7 \pm 1.90^{\mathrm{a}}$ & $\mathrm{NS}$ \\
42 & $26.9 \pm 1.79^{\mathrm{a}}$ & $26.8 \pm 1.97^{\mathrm{ab}}$ & $\mathrm{NS}$ \\
Hemoglobin (g/dL) & & & \\
0 & $7.43 \pm 0.289$ & $6.43 \pm 0.371^{\mathrm{b}}$ & $\mathrm{NS}$ \\
4 & $7.31 \pm 0.495$ & $7.28 \pm 0.270^{\mathrm{ab}}$ & $\mathrm{NS}$ \\
7 & $6.75 \pm 0.151$ & $7.76 \pm 0.506^{\mathrm{a}}$ & $\mathrm{NS}$ \\
14 & $6.94 \pm 0.389$ & $7.48 \pm 0.262^{\mathrm{ab}}$ & $\mathrm{NS}$ \\
21 & $7.50 \pm 0.486$ & $8.17 \pm 0.519^{\mathrm{a}}$ & $\mathrm{NS}$ \\
28 & $7.12 \pm 0.155$ & $7.11 \pm 0.361^{\mathrm{ab}}$ & $\mathrm{NS}$ \\
35 & $7.33 \pm 0.219$ & $7.46 \pm 0.338^{\mathrm{ab}}$ & $\mathrm{NS}$ \\
42 & $7.24 \pm 0.062$ & $7.69 \pm 0.248^{\mathrm{a}}$ & $\mathrm{NS}$ \\
\hline
\end{tabular}

NS, differences between the two groups at each sampling time were not statistically significant; SE, standard error.

Values (means $\pm \mathrm{SE}$ of three replicates) in each group of parameters with the same superscript did not significantly differ $(p>0.05)$ based on Duncan's multiple range test.
Table 2. Total protein and cholesterol concentrations measured in the plasma of starved and fed olive flounder, Paralichthys olivaceus, $0,4,7,11,14,21,28,35$, and 42 days after the start of the experiment

\begin{tabular}{cccc}
\hline $\begin{array}{c}\text { Time } \\
\text { (days) }\end{array}$ & Fed & Starved & $\begin{array}{c}\text { Fed vs } \\
\text { starved }\end{array}$ \\
\hline Total protein $(\mathrm{g} / \mathrm{dL})$ & & & \\
0 & $4.45 \pm 0.132^{\mathrm{abc}}$ & $4.37 \pm 0.060^{\mathrm{a}}$ & $\mathrm{NS}$ \\
4 & $4.60 \pm 0.200^{\mathrm{ab}}$ & $4.22 \pm 0.078^{\mathrm{a}}$ & $\mathrm{NS}$ \\
7 & $3.99 \pm 0.095^{\mathrm{c}}$ & $3.42 \pm 0.029^{\mathrm{bc}}$ & $* *$ \\
14 & $4.74 \pm 0.247^{\mathrm{ab}}$ & $3.44 \pm 0.080^{\mathrm{bc}}$ & $* *$ \\
21 & $4.86 \pm 0.230^{\mathrm{a}}$ & $3.58 \pm 0.246^{\mathrm{b}}$ & $*$ \\
28 & $4.56 \pm 0.020^{\mathrm{ab}}$ & $3.38 \pm 0.040^{\mathrm{bc}}$ & $* *$ \\
35 & $4.46 \pm 0.113^{\mathrm{abc}}$ & $3.22 \pm 0.011^{\mathrm{c}}$ & $* *$ \\
42 & $4.20 \pm 0.145^{\mathrm{bc}}$ & $2.74 \pm 0.062^{\mathrm{d}}$ & $* *$ \\
Total cholesterol $(\mathrm{mg} / \mathrm{dL})$ & & \\
0 & $304 \pm 7.9^{\mathrm{a}}$ & $297 \pm 24.4$ & $\mathrm{NS}$ \\
4 & $248 \pm 4.7^{\mathrm{ab}}$ & $262 \pm 3.0$ & $\mathrm{NS}$ \\
7 & $246 \pm 10.7^{\mathrm{b}}$ & $210 \pm 11.7$ & $\mathrm{NS}$ \\
14 & $297 \pm 28.0^{\mathrm{ab}}$ & $291 \pm 28.4$ & $\mathrm{NS}$ \\
21 & $295 \pm 11.0^{\mathrm{ab}}$ & $289 \pm 55.4$ & $\mathrm{NS}$ \\
28 & $283 \pm 18.5^{\mathrm{ab}}$ & $267 \pm 24.5$ & NS \\
35 & $272 \pm 10.7^{\mathrm{ab}}$ & $283 \pm 30.2$ & $\mathrm{NS}$ \\
42 & $270 \pm 27.1^{\mathrm{ab}}$ & $310 \pm 30.4$ & $\mathrm{NS}$ \\
\hline
\end{tabular}

NS, differences between the two groups at each sampling time were not statistically significant; SE, standard error.

Values (means $\pm \mathrm{SE}$ of three replicates) in each group of parameters with the same superscript did not significantly differ $(p>0.05)$ based on Duncan's multiple range test. Asterisks indicate significant $(* \mathrm{p}<0.05$, ** $\mathrm{p}<0.01$ ) differences between the two groups.

$\mathrm{p}<0.05)$. No variation in total cholesterol was observed in starved fish; values were maintained at a constant mean concentration of $276.1 \mathrm{mg} / \mathrm{dL}$. In contrast, values in fed fish had significantly decreased on day $7(19.1 \%$ of the initial value, $\mathrm{p}<0.05)$. However, total cholesterol did not significantly vary between two groups at any sampling time throughout the experiment ( $\mathrm{p}>0.05$ ).

The AST concentrations ranged from $9.2 \pm 0.62$ to $20.2 \pm 2.62 \mathrm{IU} / \mathrm{L}$ and from $7.2 \pm 1.35$ to $20.8 \pm 0.73 \mathrm{IU} / \mathrm{L}$ in the fed and starved fish, respectively; values had significantly decreased in fed fish by day 42 (54.5\% of the initial value) and in starved fish on days 14 and $42(38.0 \%$ and $65.4 \%$ of the initial value, respectively) $(\mathrm{p}<0.05$; Table 3$)$. ALT concentrations ranged from $1.67 \pm 0.192$ to $4.78 \pm 0.294 \mathrm{IU} / \mathrm{L}$ and from $1.78 \pm 0.111$ to $5.00 \pm 0.289 \mathrm{IU} / \mathrm{L}$ in fed and starved fish, respectively; values had significantly decreased in fed fish on days $7,14,35$, and $42(40.5 \%$ to $64.2 \%$ of the initial value) and in starved fish on days $7,14,28$, and $42(57.8 \%$ to $64.4 \%$ of the initial value) $(\mathrm{p}<0.05)$. However, the AST and ALT concentrations of the fed and starved groups did not significantly differ at any sampling time throughout the experiment $(\mathrm{p}>0.05)$.

No significant variation was observed in plasma glucose 
Table 3. Aspartate aminotransferase (AST) and alanine aminotransferase (ALT) concentrations measured in the plasma of starved and fed olive flounder, Paralichthys olivaceus, 0, 4, 7, 11, $14,21,28,35$, and 42 days after the start of the experiment

\begin{tabular}{cccc}
\hline $\begin{array}{c}\text { Time } \\
\text { (days) }\end{array}$ & Fed & Starved & $\begin{array}{c}\text { Fed vs } \\
\text { starved }\end{array}$ \\
\hline $\begin{array}{c}\text { AST (IU/L) } \\
0\end{array}$ & $20.2 \pm 2.62^{\mathrm{a}}$ & $20.8 \pm 0.73^{\mathrm{a}}$ & $\mathrm{NS}$ \\
4 & $14.4 \pm 3.35^{\mathrm{ab}}$ & $14.9 \pm 1.46^{\mathrm{abc}}$ & $\mathrm{NS}$ \\
7 & $14.1 \pm 3.44^{\mathrm{ab}}$ & $14.2 \pm 3.93^{\mathrm{abc}}$ & $\mathrm{NS}$ \\
14 & $12.4 \pm 3.01^{\mathrm{ab}}$ & $12.9 \pm 3.66^{\mathrm{bc}}$ & $\mathrm{NS}$ \\
21 & $13.6 \pm 3.22^{\mathrm{ab}}$ & $18.7 \pm 2.39^{\mathrm{ab}}$ & $\mathrm{NS}$ \\
28 & $13.6 \pm 3.09^{\mathrm{ab}}$ & $19.7 \pm 1.83^{\mathrm{ab}}$ & $\mathrm{NS}$ \\
35 & $12.4 \pm 4.33^{\mathrm{ab}}$ & $14.3 \pm 1.17^{\mathrm{abc}}$ & $\mathrm{NS}$ \\
42 & $9.2 \pm 0.62^{\mathrm{b}}$ & $7.2 \pm 1.35^{\mathrm{c}}$ & $\mathrm{NS}$ \\
ALT (IU/L) & & & \\
0 & $4.67 \pm 1.093^{\mathrm{a}}$ & $5.00 \pm 0.289^{\mathrm{a}}$ & $\mathrm{NS}$ \\
4 & $3.50 \pm 0.536^{\mathrm{ab}}$ & $4.44 \pm 0.988^{\mathrm{a}}$ & $\mathrm{NS}$ \\
7 & $1.67 \pm 0.192^{\mathrm{c}}$ & $2.11 \pm 0.484^{\mathrm{b}}$ & $\mathrm{NS}$ \\
14 & $2.78 \pm 0.444^{\mathrm{bc}}$ & $1.89 \pm 0.111^{\mathrm{b}}$ & $\mathrm{NS}$ \\
21 & $4.78 \pm 0.294^{\mathrm{a}}$ & $4.22 \pm 0.364^{\mathrm{a}}$ & $\mathrm{NS}$ \\
28 & $3.28 \pm 0.494^{\mathrm{abc}}$ & $1.78 \pm 0.111^{\mathrm{b}}$ & $\mathrm{NS}$ \\
35 & $2.67 \pm 0.192^{\mathrm{bc}}$ & $3.78 \pm 0.294^{\mathrm{a}}$ & $\mathrm{NS}$ \\
42 & $2.22 \pm 0.222^{\mathrm{bc}}$ & $1.89 \pm 0.111^{\mathrm{b}}$ & $\mathrm{NS}$ \\
\hline
\end{tabular}

NS, differences between the two groups at each sampling time were not statistically significant; SE, standard error.

Values (means $\pm \mathrm{SE}$ of three replicates) in each group of parameters with the same superscript did not significantly differ $(p>0.05)$ based on Duncan's multiple range test.

of fed and starved fish; the two groups maintained constant mean concentrations of 17.4 and $16.7 \mathrm{mg} / \mathrm{dL}$, respectively (Table 4). Moreover, no significant differences in plasma glucose were recorded between the two groups at any sampling time throughout the experiment ( $p>0.05)$. Cortisol concentrations ranged from $2.67 \pm 0.333$ to $14.44 \pm 3.602$ $\mathrm{ng} / \mathrm{mL}$ and from $2.44 \pm 0.444$ to $12.33 \pm 3.032 \mathrm{ng} / \mathrm{mL}$ in the fed and starved fish, respectively; values had significantly decreased in fed fish on day 35 ( $78.2 \%$ of the initial value) and in starved fish on days $4,7,14,28,35$, and $42(53.1 \%$ to $80.2 \%$ of the initial value, $\mathrm{p}<0.05$ ). However, no significant variation in cortisol concentrations was detected between the fed and starved groups at any sampling time throughout the experiment $(\mathrm{p}>0.05)$.

The effects of starvation on non-specific immune response parameters are presented in Table 5. The concentrations of plasma lysozyme in the fed group after day 4 (mean concentration of 30.8 units $/ \mathrm{mL}$ ) were statistically similar to the value ( $32.1 \mathrm{units} / \mathrm{mL}$ ) observed on day 0 ( $p>0.05$ ), whereas concentrations in the starved group significantly increased from $31.4 \pm 4.26$ units $/ \mathrm{mL}$ on day 0 to $58.7 \pm 7.49$ to $70.4 \pm 9.15$ units $/ \mathrm{mL}$ on day 21 and thereafter $(p<0.05)$. As a result, lysozyme concentrations in the starved group were significantly higher than those in the fed
Table 4. Glucose and cortisol concentrations measured in the plasma of starved and fed olive flounder, Paralichthys olivaceus, $0,4,7,11,14,21,28,35$, and 42 days after the start of the experiment

\begin{tabular}{cccc}
\hline $\begin{array}{l}\text { Time } \\
\text { (days) }\end{array}$ & Fed & Starved & $\begin{array}{c}\text { Fed vs } \\
\text { starved }\end{array}$ \\
\hline $\begin{array}{c}\text { Glucose }(\mathrm{mg} / \mathrm{dL}) \\
0\end{array}$ & $18.7 \pm 2.33$ & $18.0 \pm 0.00$ & $\mathrm{NS}$ \\
4 & $17.4 \pm 2.80$ & $17.6 \pm 0.89$ & $\mathrm{NS}$ \\
7 & $16.3 \pm 2.03$ & $16.0 \pm 1.17$ & $\mathrm{NS}$ \\
14 & $19.6 \pm 1.16$ & $16.9 \pm 0.91$ & $\mathrm{NS}$ \\
21 & $17.7 \pm 1.59$ & $15.3 \pm 1.20$ & $\mathrm{NS}$ \\
28 & $15.6 \pm 0.77$ & $15.6 \pm 1.18$ & $\mathrm{NS}$ \\
35 & $15.1 \pm 0.89$ & $17.7 \pm 0.69$ & $\mathrm{NS}$ \\
42 & $18.4 \pm 1.61$ & $16.8 \pm 0.44$ & $\mathrm{NS}$ \\
Cortisol (ng/mL) & & & \\
0 & $12.23 \pm 1.011^{\mathrm{ab}}$ & $12.33 \pm 3.032^{\mathrm{a}}$ & $\mathrm{NS}$ \\
4 & $9.22 \pm 3.964^{\mathrm{abc}}$ & $5.56 \pm 1.176^{\mathrm{bc}}$ & $\mathrm{NS}$ \\
7 & $11.22 \pm 3.571^{\mathrm{ab}}$ & $5.78 \pm 2.296^{\mathrm{bc}}$ & $\mathrm{NS}$ \\
14 & $9.22 \pm 1.495^{\mathrm{abc}}$ & $4.56 \pm 1.060^{\mathrm{bc}}$ & $\mathrm{NS}$ \\
21 & $6.89 \pm 0.949^{\mathrm{abc}}$ & $8.44 \pm 1.281^{\mathrm{ab}}$ & $\mathrm{NS}$ \\
28 & $14.44 \pm 3.602^{\mathrm{b}}$ & $5.78 \pm 1.310^{\mathrm{bc}}$ & $\mathrm{NS}$ \\
35 & $2.67 \pm 0.333^{\mathrm{c}}$ & $2.44 \pm 0.444^{\mathrm{c}}$ & $\mathrm{NS}$ \\
42 & $6.00 \pm 1.836^{\mathrm{bc}}$ & $4.56 \pm 0.111^{\mathrm{bc}}$ & $\mathrm{NS}$ \\
\hline
\end{tabular}

NS, differences between the two groups at each sampling time were not statistically significant; SE, standard error.

Values (means $\pm \mathrm{SE}$ of three replicates) in each group of parameters with the same superscript did not significantly differ $(p>0.05)$ based on Duncan's multiple range test.

group from day 21 onwards $(\mathrm{p}<0.01$ or $\mathrm{p}<0.05)$.

\section{DISCUSSION}

Previous studies have reported significant reductions in

Table 5. Plasma lysozyme concentrations measured in the plasma of starved and fed olive flounder, Paralichthys olivaceus, 0, 4, 7, $11,14,21,28,35$, and 42 days after the start of the experiment

\begin{tabular}{lccc}
\hline $\begin{array}{l}\text { Time } \\
\text { (days) }\end{array}$ & Fed & Starved & $\begin{array}{c}\text { Fed vs } \\
\text { starved }\end{array}$ \\
\hline $\begin{array}{l}\text { Lysozyme (units/mL) } \\
0\end{array}$ & $32.1 \pm 6.44^{\mathrm{ab}}$ & $31.4 \pm 4.26^{\mathrm{b}}$ & $\mathrm{NS}$ \\
4 & $32.5 \pm 4.17^{\mathrm{ab}}$ & $39.4 \pm 2.74^{\mathrm{b}}$ & $\mathrm{NS}$ \\
7 & $28.8 \pm 0.61^{\mathrm{ab}}$ & $38.9 \pm 6.01^{\mathrm{b}}$ & $\mathrm{NS}$ \\
14 & $20.5 \pm 7.00^{\mathrm{b}}$ & $33.0 \pm 7.54^{\mathrm{b}}$ & $\mathrm{NS}$ \\
21 & $37.0 \pm 1.45^{\mathrm{a}}$ & $61.9 \pm 1.72^{\mathrm{a}}$ & $* *$ \\
28 & $31.9 \pm 6.33^{\mathrm{ab}}$ & $70.4 \pm 9.15^{\mathrm{a}}$ & $*$ \\
35 & $31.9 \pm 1.54^{\mathrm{ab}}$ & $58.7 \pm 7.49^{\mathrm{a}}$ & $*$ \\
42 & $32.9 \pm 5.46^{\mathrm{ab}}$ & $67.8 \pm 5.39^{\mathrm{a}}$ & $* *$ \\
\hline
\end{tabular}

NS, differences between the two groups at each sampling time were not statistically significant; $\mathrm{SE}$, standard error.

Values (means $\pm \mathrm{SE}$ of three replicates) in each group of parameters with the same superscript did not significantly differ $(p>0.05)$ based on Duncan's multiple range test. Asterisks indicate significant $(* \mathrm{p}<0.05$, ** $\mathrm{p}<0.01)$ differences between the two groups. 
the body weight of starved fish compared to fed fish in a number of species, including brook trout, Salvelinus fontinalis (Heming and Paleczny, 1987), coho salmon (Larsen et al., 2001), European sea bass, Dicentrarchus labrax (Caruso et al., 2011; Chatzifotis et al., 2011), channel catfish, Ictalurus punctatus (Small, 2005) and European eel, Anguilla anguilla (Caruso et al., 2010). Similar results were observed in the present study, as starved fish exhibited a significant decrease in body weight, with an $11.9 \%$ loss of initial weight after the 42-day starvation trial. Our findings were also consistent with the results of previous studies of olive flounder that monitored fish for 12 weeks after starvation (Hur et al., 2006; Park et al., 2006).

Given the fact that starvation is a major stressor experienced by fish, primary responses to stress can be described as the activation of the neuro-endocrine system through the release of stress-related hormones (cathecolamines and cortisol) in the blood, while secondary responses include hematological and biochemical changes (Caruso et al., 2010). In the cases of European eel, northern pike, and lake sturgeon, Acipenser fulvescens, both increases and decreases in hematological values have been reported in fish as a consequence of food restriction (Johansson-Sjobeck et al., 1975; Ince and Thorpe, 1976; Gillis and Ballantyne, 1996; Caruso et al., 2010). Nonetheless, in the present study, hematocrit and hemoglobin in the olive flounder did not differ between fed and starved groups throughout the experiment. Similarly, previous studies of olive flounder and red porgy have found that fed and starved fish did not significantly differ in these hematological parameters (Caruso et al., 2012; Park et al., 2012). However, the patterns of changes in these parameters differed across species throughout the starvation period for each experimental group. Namely, in the present study and in Park et al. (2012), fed olive flounder exhibited a significant decrease in hematocrit at an early stage and an increase in hemoglobin in starved fish later in the experiment. In contrast, neither fed nor starved red porgy exhibited changes in hematocrit or hemoglobin with time over the entire experiment (Caruso et al., 2012). Park et al. (2012) suggested that responses to starvation are species specific; the present results provide additional support for this hypothesis.

Pronounced and significant decreases in plasma total protein concentrations have been observed in several starved fish species, including European eel (Dave et al., 1975), brook trout (Heming and Paleczny, 1987), and Senegalese sole, Solea senegalensis (Costas et al., 2011). Furthermore, in olive flounder starved for 8 weeks, Cho (2009) reported a linear decrease in plasma total protein with a week of starvation; he obtained the following relationship between plasma total protein and starvation: Y
$($ total protein $)=-0.13 \mathrm{X}($ week of starvation $)+1.54, \mathrm{R}^{2}=$ 0.979 . The author also indicated that plasma total protein could serve as a good index of the severity of starvation for olive flounder (Cho, 2009). A similar result was observed in the present study, i.e., plasma total protein concentrations in starved fish significantly decreased with an increase in starvation time, and the values were significantly lower than those in fed fish from day 7 onwards. The relationship between plasma total protein and starvation was also similar to that observed by Cho (2009): Y (total protein) $=-0.03 \mathrm{X}$ (week of starvation) $+4.02, \mathrm{R}^{2}=0.718$. Therefore, these results confirm the results of Cho (2009), suggesting a role of total protein as a fuel source in olive flounder.

In the present study, no significant variation in plasma total cholesterol concentration was detected between fed and starved flounder throughout the experiment. Similar to other parameters, results from previous studies regarding the effect of starvation on total cholesterol are conflicting. Increases, decreases, or no change have been reported with equal frequency in fish after starvation (Ince and Thorpe, 1976; Heming and Paleczny, 1987; Chatzifotis et al., 2011). These varying responses are consistent with the suggestion that the concentration of cholesterol varies depending on the duration of starvation and may exhibit diel patterns (Chatzifotis et al., 2011).

The AST and ALT concentrations were not affected by starvation in the present study, likely due to high variation in replicates within the same sampling time. Similar results were documented in a study of olive flounder starved for 8 weeks, in which AST and ALT concentrations of the fed and starved groups did not differ throughout the experiment (Cho, 2009). In that study, plasma AST and ALT concentrations of fed and starved flounder ranged from 11.0 to $28.3 \mathrm{IU} / \mathrm{L}$ and from 1.3 to $4.3 \mathrm{IU} / \mathrm{L}$, respectively, and were similar to the values observed in fed and starved flounder in the present study (7.2 to $20.8 \mathrm{IU} / \mathrm{L}$ and 1.7 to 5.0 IU/L, respectively). In contrast, Park et al. (2012) reported different findings, i.e., AST and ALT concentrations in olive flounder starved for 4 weeks were significantly elevated by starvation stress, suggesting that starvation places physiological burdens on the liver and spleen. Our results and those of Park et al. (2012) may have differed because factors such as the physiological status of experimental fish coupled with rearing conditions such as water temperature $\left(22^{\circ} \mathrm{C}\right.$ vs $\left.20^{\circ} \mathrm{C}\right)$ and density at the start of the experiment $(1.84 \mathrm{~kg} / \mathrm{ton}$ vs $2.71 \mathrm{~kg} / \mathrm{ton})$ differed between the two studies.

Starvation is known to induce different responses in blood glucose concentration, depending on the duration of starvation as well as on species-specific differences in metabolism and the regulation thereof (Caruso et al., 2010). Reductions in plasma glucose concentrations have been reported in response to starvation periods of 28,20 , and 42 
days in some salmonids, including brook trout (Heming and Paleczny, 1987), chinook salmon, O. tshawytscha (Barton et al., 1988) and rainbow trout, O. mykiss (Farbridge and Leatherland, 1992). In contrast, a significant increase in glucose concentrations was observed in European eel between 47 and 96 days after starvation (Dave et al., 1975). In olive flounder, glucose concentrations of starved fish increased up until 4 weeks compared to fed fish, but after 4 weeks, concentrations decreased to day-0 values (Park et al., 2012). On the other hand, no differences were observed between fed and starved groups of jundia, Rhamdia quelen, after starvation for a period of 21 days (Barcellos et al., 2010), of European sea bass starved for 97 days (Chatzifotis et al., 2011), of Senegalese sole starved for 21 days (Costas et al., 2011), or of red porgy starved for 14 days (Caruso et al., 2012). In the present study, plasma glucose concentrations in flounder starved from 0 to 42 days remained constant, suggesting that a metabolic reorganization occurred to maintain glucose concentrations without dietary sources. These results are consistent with previous observations (Gillis and Ballantyne, 1996; Costas et al., 2011; Caruso et al., 2012). These studies emphasized that maintaining glucose concentrations throughout starvation is, in general, particularly important because glucose is an essential fuel for a number of tissues, and the maintenance of glucose concentrations is achieved via increases in glycogenolysis and gluconeogenesis. These responses also reflect, in part, the fluctuating values of glucose concentrations in starved olive flounder at the early stage of the study of Park et al. (2012).

Plasma cortisol concentrations have been consistently reported to increase in response to starvation or malnutrition in homeothermic species such as mammals (Costas et al., 2011; Caruso et al., 2012). However, starvation has induced a variety of patterns of changes in teleosts. For example, in chinook salmon and channel catfish, cortisol concentrations of starved fish decreased after starvation compared to fed fish (Barton et al., 1988; Small, 2005). In contrast, species such as jundia, Senegalese sole, and red porgy exhibited increased cortisol concentrations after starvation (Barcellos et al., 2010; Costas et al., 2011; Caruso et al., 2012). In addition, other species such as rainbow trout and sunshine bass, Morone chrysops $\times$ M. saxatilis, did not exhibit consistent effects (Farbridge and Leatherland, 1992; Davis and Gaylord, 2011). In olive flounder, Park et al. (2012) reported that plasma cortisol concentrations were high in the fed group at 4 weeks but did not change in the starved group during the 12 weeks of the experiment; eventually, at 4 weeks, the cortisol concentrations of the fed and starved groups significantly differed. Park et al. (2012) did not measure cortisol before 4 weeks of starvation, yet they speculated that cortisol would be significantly higher in starved fish than in fed fish prior to 4 weeks of starvation, as cortisol and its metabolically related products are considered to increase in early stages of starvation stress, allowing rapid adaptation to a life-threatening process. In the present study, however, plasma cortisol concentrations significantly decreased at some point during the experiment in both fed and starved fish, but no significant variation in concentrations were detected between fed and starved groups throughout the experiment. Thus, starvation appeared to have no direct effect on plasma cortisol concentration in the present study.

Because starvation is a chronic stress condition, it can lead to growth inhibition, impaired reproduction, and immune responses (Caruso et al., 2010). Immunity and antioxidant ability are the most important physiological functions in fish to avoid disease, and changes in these abilities can be observed in fish by monitoring various related indicators. Lysozyme is one important immunity factor used by fish to resist pathogenic infection (Feng et al., 2011). The enhancement, depression, or stagnation of lysozyme concentration may occur depending on fish species, age, size, and sex of fish, as well as environmental factors (Caruso et al., 2012). No significant effects were observed in plasma lysozyme levels of European sea bass and red porgy exposed to 31 and 14 days starvation, respectively (Caruso et al., 2011,2012). Caruso et al. (2010) reported that starvation stress caused a decrease in the plasma lysozyme concentration of European eel starved for 31 days. In contrast, Feng et al. (2011) reported that the serum lysozyme concentration of juvenile Chinese sturgeon, A. sinensis, generally increased as the starvation time increased. Furthermore, they observed a significant difference in lysozyme levels in juveniles starved for 43 days compared to those starved for 1 to 19 days, suggesting that starvation affected the antioxidant capability of the fish (Feng et al., 2011). Similarly, in the present study, the plasma lysozyme concentrations in the starved group had significantly increased by day 21 (and thereafter) and were thus significantly higher than the values in the fed group from day 21 onwards. This finding indicates that the nonspecific immunity of olive flounder was maintained fairly well during the starvation period, as suggested by Feng et al. (2011).

Overall, our data indicate that starvation did not act as a strong physiological stressor for olive flounder, as it did not significantly compromise their health status despite food limitation. In fact, no significant differences were observed in plasma glucose of fed and starved fish, and the two groups maintained constant glucose concentrations during the starvation period, suggesting a compensatory metabolic mechanism. Plasma total protein concentrations were significantly lower in the starved fish from day 7 onwards, suggesting a need for protein as a first fuel source. Furthermore, plasma lysozyme concentrations were 
significantly higher in starved flounder from day 21 onwards, indicating a non-specific immunity of fish allowing them to maintain fairly good health during starvation. This result confirms that the response to shortterm (less than about 1.5 months) starvation in olive flounder consisted of a readjustment of metabolism rather than the activation of an alarm-stress response.

\section{ACKNOWLEDGMENTS}

This work was funded by a grant from the National Fisheries Research and Development Institute of Korea (RP-2014-AQ-011).

\section{REFERENCES}

Bandeen, J. and J. F. Leatherland. 1997. Changes in the proximate composition of juvenile white suckers following re-feeding after a prolonged fast. Aquac. Int. 5:327-337.

Barcellos, L. J. G., A. Marqueze, M. Trapp, R. M. Quevedo, and D. Ferreira. 2010. The effects of fasting on cortisol, blood glucose and liver and muscle glycogen in adult jundia Rhamdia quelen. Aquaculture 300:231-236.

Barton, B. A., C. B. Schreck, and L. G. Fowler. 1988. Fasting and diet content affect stress-induced changes in plasma glucose and cortisol in juvenile chinook salmon. Prog. Fish Cult. 50:16-22.

Caruso, G., G. Maricchiolo, V. Micale, L. Genovese, R. Caruso, and M. G. Denaro. 2010. Physiological responses to starvation in the European eel (Anguilla anguilla): effects on haematological, biochemical, non-specific immune parameters and skin structures. Fish Physiol. Biochem. 36:71-83.

Caruso, G., M. G. Denaro, R. Caruso, F. Mancari, L. Genovese, and G. Maricchiolo. 2011. Response to short term starvation of growth, haematological, biochemical and non-specific immune parameters in European sea bass (Dicentrarchus labrax) and blackspot sea bream (Pagellus bogaraveo). Mar. Environ. Res. 72:46-52.

Caruso, G., M. G. Denaro, R. Caruso, L. Genovese, F. Mancari, and G. Maricchiolo. 2012. Short fasting and refeeding in red porgy (Pagrus pagrus, Linnaeus 1758): Response of some haematological, biochemical and non specific immune parameters. Mar. Environ. Res. 81:18-25.

Chatzifotis, S., M. Papadaki, S. Despoti, C. Roufidou, and E. Antonopoulou. 2011. Effect of starvation and re-feeding on reproductive indices, body weight, plasma metabolites and oxidative enzymes of sea bass (Dicentrarchus labrax). Aquaculture 316:53-59.

Cho, S. H. 2009. Effect of fasting and refeeding on growth and blood chemistry in juvenile olive flounder Paralichthys olivaceus L. J. Aquac. 22:11-15.

Cho, S. H., S. -M. Lee, B. H. Park, S. -C. Ji, J. Lee, J. Bae, and S. Y. Oh. 2006. Compensatory growth of juvenile olive flounder, Paralichthys olivaceus L., and changes in proximate composition and body condition indexes during fasting and after refeeding in summer season. J. World Aquac. Soc. 37:168-174.
Collins, A. L. and T. A. Anderson. 1995. The regulation of endogeneous energy stores during starvation and refeeding in the somatic tissues of the golden perch. J. Fish Biol. 47:10041015.

Costas, B., C. Aragao, I. Ruiz-Jarabo, L. Vargas-Chacoff, F. J. Arjona, M. T. Dinis, J. M. Mancera, and L. E. C. Conceicao. 2011. Feed deprivation in Senegalese sole (Solea senegalensis Kaup, 1858) juveniles: effects on blood plasma metabolites and free amino acid levels. Fish Physiol. Biochem. 37:495-504.

Dave, G., M. -L. Johansson-Sjobeck, A. Larsson, K. Lewander, and U. Lidman. 1975. Metabolic and hematological effects of starvation in the European eel, Anguilla anguilla L. I. Carbohydrate, lipid, protein and inorganic ion metabolism. Comp. Biochem. Physiol. A. Physiol. 52A:423-430.

Davis, K. B. and T. G. Gaylord. 2011. Effect of fasting on body composition and responses to stress in sunshine bass. Comp. Biochem. Physiol. A. Mol. Integr. Physiol. 158A:30-36.

Farbridge, K. J. and J. F. Leatherland. 1992. Plasma growth hormone levels in fed and fasted rainbow trout (Oncorhynchus mykiss) are decreased following handling stress. Fish Physiol. Biochem. 10:67-73.

Feng, G., X. Shi, X. Huang, and P. Zhuang. 2011. Oxidative stress and antioxidant defenses after long-term fasting in blood of Chinese sturgeon (Acipenser sinensis). Procedia Environ. Sci. 8:469-475.

Gillis, T. E. and J. S. Ballantyne. 1996. The effects of starvation on plasma free amino acid and glucose concentrations in lake sturgeon. J. Fish Biol. 49:1306-1316.

Heming, T. A. and E. J. Paleczny. 1987. Compositional changes in skin mucus and blood serum during starvation of trout. Aquaculture 66:265-273.

Hemre, G. -I. Ø. Lie, and A. Sundby. 1993. Dietary carbohydrate utilization in cod (Gadus morhua): metabolic responses to feeding and fasting. Fish Physiol. Biochem. 10:455-463.

Hur, J. W., J. H. Jo, and I. -S. Park. 2006a. Effects of long-term starvation on hepatocyte ultrastructure of olive flounder Paralichthys olivaceus. Ichthyol. Res. 53:306-310.

Hur, J. W., S. R. Woo, J. H. Jo, and I. -S. Park. 2006b. Effects of starvation on kidney melano-macrophage center in olive flounder, Paralichthys olivaceus (Temminck and Schlegel). Aquac. Res. 37:821-825.

Ince, B. W. and A. Thorpe. 1976. The effects of starvation and force-feeding on the metabolism of the northern pike, Esox lucius L. J. Fish Biol. 8:79-88.

Johansson-Sjobeck, M. -L., G. Dave, A. Larsson, K. Lewander, and U. Lidman. 1975. Metabolic and hematological effects of starvation in the European eel, Anguilla anguilla L. II. Hematology. Comp. Biochem. Physiol. A Physiol. 52A:431434.

Larsen, D. A., B. R. Beckman, and W. W. Dickhoff. 2001. The effect of low temperature and fasting during the winter on metabolic stores and endocrine physiology (insulin, insulinlike growth factor-I, and thyroxine) of coho salmon, Oncorhynchus kisutch. Gen. Comp. Endocrinol. 123:308-323.

Ogata, H. Y., H. Oku, and T. Murai. 2002. Growth performance and macronutrient retention of offspring from wild and selected red sea bream (Pagrus major). Aquaculture 206:279287. 
Park, I. -S., J. W. Hur, and J. W. Choi. 2012. Hematological responses, survival, and respiratory exchange in the olive flounder, Paralichthys olivaceus, during starvation. Asian Australas. J. Anim. Sci. 25:1276-1284.

Park, I. -S., S. R. Woo, E. -M. Kim, and S. H. Cho. 2006. Effect of feeding and starvation on growth and phenotypic trait in olive flounder, Paralichthys olivaceus (Temminck et Schlegel). J. Aquacult. 19:183-187.

Park, I. -S., S. R. Woo, Y. -C. Song, and S. H. Cho. 2007. Effects of starvation on morphometric characteristics of olive flounder, Paralichthys olivaceus. Ichthyol. Res. 54:297-302.

Parry, R. M., R. C. Chandon, and K. M. Shahani. 1965. A rapid and sensitive assay of muramidase. Proc. Soc. Exp. Biol. Med. 119:384-386
Rueda, F. M., F. J. Martinez, S. Zamora, M. Kentouri, and P. Divanach. 1998. Effect of fasting and refeeding on growth and body composition of red porgy, Pagrus pagrus L. Aquac. Res. 29:447-452.

Shim, K. B., S. J. Lee, H. D. Yoon, C. W. Lim, Y. K. Shin, M. H. Jeong, D. G. Lee, and T. I. Park. 2012. Effects of low temperature and starvation on the physicochemical characteristics of muscle of the olive flounder Paralichthys olivaceus. Korean J. Fish. Aquat. Sci. 45:430-437.

Small, B. C. 2005. Effect of fasting on nychthemeral concentrations of plasma growth hormone $(\mathrm{GH})$, insulin-like growth factor I (IGF-I), and cortisol in channel catfish (Ictalurus punctatus). Comp. Biochem. Physiol. B, Biochem. Mol. Biol. 142B:217-223. 